\title{
Relevance of B3 lesions in breast diagnosis - frequency and therapeutic consequences
}

\section{Bedeutung von B3-Läsionen in der Brustdiagnostik - Häufigkeit und therapeutische Konsequenzen}

Authors

Christin Madjar ${ }^{1}$, James Seabert ${ }^{2}$, Annette Fisseler-Eckhoff ${ }^{3}$, Christian Gustmann ${ }^{4}$, Isabell Hoffmann ${ }^{5}$, Doris LünstrothLenk $^{6}$, Edgar Rinast ${ }^{6}$, Carla von Bruchhausen ${ }^{7}$, Helmut Madjar ${ }^{8}$, Gerald Hoffmann ${ }^{2}$

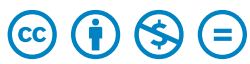

Affiliations

1 Krankenhaus Nordwest Frankfurt

2 St. Josefs Hospital Wiesbaden

3 Institut für Pathologie HELIOS HSK Wiesbaden

4 UGP MVZ Institut für Pathologie, Zytologie und Molekularpathologie GbR, Limburg,

5 Institut für Medizinische Biometrie, Epidemiologie und Informatik (IMBEI) Universitätsmedizin Mainz,

6 Mammografiescreening-Zentrum Wiesbaden

7 Radiomed Gemeinschaftspraxis für Radiologie und Nuklearmedizin, Wiesbaden,

8 Frauenarztpraxis Dr. Seabert/Prof. Madjar, Wiesbaden

Key words

B3 lesions, uncertain malignant potential, open breast biopsy, breast cancer risk, interventional diagnostics

Schlüsselwörter

B3-Läsionen, unsicheres malignes Potenzial, offene Brust-

biopsie, Brustkrebsrisiko, interventionelle Diagnostik

Bibliography

DOI https://doi.org/10.1055/a-0646-6554

Senologie 2018; 15: 153-159

(c) Georg Thieme Verlag KG, Stuttgart · New York

ISSN 1611-6453

Correspondence

Prof. Dr. med. Helmut Madjar

Praxis für Gynäkologie, An den Quellen 1, 65183 Wiesbaden

Tel.: ++49/611/302832

Fax: ++ 49/6 11/37 0440

helmut.madjar@web.de

(

Deutsche Version unter:

https://doi.org/10.1055/a-0646-6554

\section{ZUSAMMENFASSUNG}

Fortschritte in der bildgebenden Brustdiagnostik und die Einführung von minimalinvasiven Nadelbiopsien haben neben einer besseren Brustkrebsfrüherkennung auch die Zahl falsch positiver benigner Befunde und die Entdeckung von soge- nannten Risikoläsionen erhöht. Letztere werden histologisch als B3-Läsionen eingeteilt. Hinter diesen verbergen sich in unterschiedlicher Häufigkeit Malignome, sodass die Entscheidung zu einer Operation oft kontrovers diskutiert wird. Mit der Auswertung unserer Ergebnisse im Rahmen einer retrospektiven Studie wollen wir eine Entscheidungshilfe liefern. Insgesamt wurden 307 Stanz- oder Vakuumbiopsien (VSB) durchgeführt, die eine B3-Läsion ergaben. Die häufigsten Befunde waren: Papillome (44\%), ADH (22,8\%), FEA (9,4\%), Phylloidestumoren (6,5\%), radiäre Narben (5,9\%), LIN 1 (4,9\%), komplexe Fibroadenome (3,3\%) und LIN 2 (1,6\%). Die Häufigkeiten variierten erheblich in Abhängigkeit davon, ob die Abklärung durch Stanzbiopsie oder VSB vorgenommen wurde. Die stereotaktisch geführte VSB wurde in der Regel bei radiologischem Mikrokalk ohne sonografisches Korrelat durchgeführt. Sonografisch auffällige Befunde wurden dagegen durch die Stanzbiopsie abgeklärt.

In 254 Fällen erfolgte eine Operation, die in 27,2\% der Fälle eine bösartige Histologie ergab: 24,6\% der 114 Papillome, 48,4\% der 62 ADH, 2,4\% der insgesamt 41 FEA, komplexen Fibroadenome und Phylloidestumoren, 20,7\% der 29 LIN-1Läsionen und radiären Narben sowie $50 \%$ der 8-LIN-2-Läsionen, Adenomyoepitheliome und atypischen apokrinen Metaplasien.

Daraus folgt, dass die Indikation zur offenen Biopsie nach einer Nadelbiopsie mit dem Ergebnis einer B3-Läsion grundsätzlich gegeben ist. Jedoch kann in Einzelfällen insbesondere bei geringerer Malignomrate nach klinisch-pathologischer Konferenz und kritischer Bewertung der bildgebenden Diagnostik auf die Operation verzichtet werden. Ein sorgfältiges Follow-up ist aber unabdingbar

\section{ABSTRACT}

With improvements in breast imaging and minimally invasive interventions, detection of early breast cancer has increased. However, with the improved diagnostic capabilities, the risk of false-positive benign lesions as well as lesions classified as B3 by histopathology has also increased. Varying rates of malignancies are associated with B3 lesions, raising the question of whether such lesions should always be surgically removed. The results of our retrospective analysis should assist in this decision-making process. 
307 core needle or vacuum-assisted needle biopsies in which B3 lesions were found were examined. The most common lesions were intraductal papillomas (44\%), atypical ductal hyperplasia (22.8\%), flat epithelial atypia (9.4\%), phyllodes tumours (6.5\%), radial scars (5.9\%), LIN 1 (4.9\%), complex fibroadenomas $(3.3 \%)$ and LIN $2(1.6 \%)$. The frequencies depended considerably on whether the tissue was obtained by core biopsy or vacuum biopsy. Stereotactic vacuum biopsy was generally performed in the case of microcalcification not apparent on sonography. Lesions visible on ultrasound had core needle biopsy.

Surgery was performed in 254 cases and a malignancy was found in $27.2 \%$ on the final histopathology. Malignancy was found in $24.6 \%$ of 114 cases initially diagnosed as intraductal papilloma. Similarly, cancer was discovered in $48.4 \%$ of the 62 cases of atypical ductal hyperplasia, in $2.4 \%$ of the 41 cases of flat epithelial atypia, complex fibroadenoma and phyllodes tumour, in $20.7 \%$ of the 29 cases of LIN 1 and radial scar as well as in $50 \%$ of the 8 cases of LIN 2, adenomyoepithelioma and atypical apocrine metaplasia.

These data indicate the necessity for complete surgical removal of a B3 lesion when it is discovered using the core needle or vacuum-assisted biopsy technique. The decision not to perform surgery can be made when the risk of associated malignancy is deemed low in the clinical pathology conference, but careful follow-up is essential.

\section{Introduction}

Improvements in breast diagnostics in the last 20 years and the introduction of nationwide mammography screening in Germany have resulted in increased detection of early breast cancer. However, there has also been an increase in false-positive results. At the same time, minimally invasive core needle biopsy or vacuum-assisted biopsy have improved so surgery can be avoided in many cases [1].

The results of most needle biopsies correlate clearly with subsequent operative histology. Some lesions are associated with varying rates of malignancy, however, or with an increased risk of later disease. The standardised B classification was devised to enable pathologists to provide clear recommendations on further investigation or treatment planning, based on the result of a needle biopsy [1 - 4].

- B1 is a normal finding. If a lesion suspected to be a tumour was biopsied, exact correlation between the imaging and the pathological result is necessary to exclude the possibility that the needle missed the lesion, giving a false-negative result.

- B2 corresponds to a definitely benign biopsy result, e. g., a fibroadenoma. However, discussion in the clinical pathology conference is recommended.

- B3 lesions are those with uncertain malignant potential. Discussion in the clinical pathology conference of what further action should be taken is always necessary.

- B4 lesions are suspicious for malignancy, but before final treatment is planned it must be clarified whether minimally invasive re-biopsy or open excision biopsy should be performed to establish the diagnosis.

- B5 lesions do not present any diagnostic difficulties as these are obvious malignant neoplasms.

B3 lesions are subdivided into heterogeneous lesions, which, though benign, can have foci of malignant change, and indicator lesions, which are regarded as potential precursors of invasive breast cancer and more often occur simultaneously [1]. These are:

- Papilloma

- Radial scar

- Phyllodes tumour
- Lobular intraepithelial neoplasia 1 (LIN 1)

- Lobular intraepithelial neoplasia 2 (LIN 2)

- Atypical ductal hyperplasia (ADH)

- Flat epithelial atypia (FEA)

- Atypical apocrine metaplasia

- Fibroadenoma with atypia (with increased proliferation or with LIN 1/LIN 2)

- Adenomyoepithelioma

An important quality attribute in curative breast diagnostics and mammography screening consists of generating as few falsepositive results as possible and performing minimally invasive investigations or even surgery. B3 lesions therefore play a particularly important part in the decision-making in clinical pathology case conferences. Scientific research in recent years has delivered partially controversial results. This can be explained by differences in patient preselection (symptomatic or screening-detected patients), by whether the lesion was mainly detectable by mammography or ultrasonography, and by whether the preoperative diagnosis was made by core needle or vacuum-assisted biopsy. Our goal when planning this study was to define the features of the different risk lesions from the mixed population of mammography screening and symptomatic patients, and to evaluate their significance for diagnostic imaging in order to assist decisionmaking in further patient management.

\section{Patients and method}

The study includes 307 biopsies from 302 patients (bilateral in five patients), 300 female and two male. Between 2004 and 2012, minimally invasive procedures that yielded a B3 lesion were performed in five different breast centres in Wiesbaden and Limburg and in the Wiesbaden Mammography Screening Centre (MSC). 86 patients had biopsies in the MSC and 216 patients (221 biopsies) in the five breast clinics. The mean age was 54 years (range $14-$ 86 years, SD 12.7 years). There were 114 vacuum-assisted biopsies and 193 core biopsies. The samples were processed in the pathology institute of Helios-HSK Wiesbaden and the pathology department of St. Vincenz Hospital Limburg, with dual reporting in each case. The findings were immediately followed up with 
surgery in 254 cases ( $83 \%$ ). These patients and the non-operated patients were followed up carefully.

This is a retrospective analysis of the treatment results and follow-up data from all of the aforementioned centres. All personal patient data were anonymised prior to inclusion in the database.

Besides descriptive analysis of categorical variables (imaging and needle biopsy method, clinical findings and operation result), the tumour size on ultrasound and in the operation specimen was calculated as a continuous variable. As regards the main aim of the study, whether the different B3 lesions are more benign or malignant, the chi-square test was used for more than two categories and related samples. The data were captured in a database using Microsoft Excel and analysed with the IBM SPSS Statistics 21 program.

\section{Results}

The frequencies of the different B3 lesions in all needle biopsies are listed in Table 1 . When the 193 core biopsies and 114 vacuum-assisted biopsies are distinguished, however, clear differences in the frequencies of the different pathological findings are shown ( $>$ Table 2,3 ).

Surgery was usually performed in the case of confirmed papilloma, ADH, FEA, phyllodes tumour, radial scar, LIN 1 and LIN 2 ( $\triangleright$ Table 4). Malignancy was found most often in papillomas, ADHs, radial scars, LIN 1 and LIN 2.

When core needle biopsy and vacuum-assisted biopsy are considered separately, there are obvious differences in the frequency of malignancy ( $\triangleright$ Table 5,6 ). If the B3 lesion was diagnosed on core biopsy, subsequent surgery found cancer in $30 \%$, but this was the case in only $22 \%$ after vacuum biopsy.

\section{Clinical features}

When the tumour sizes were compared, the median was $10 \mathrm{~mm}$ in the 94 benign lesions removed surgically, whereas the median size of the 60 malignant lesions was $15 \mathrm{~mm}$. Comparison with the clinical findings showed a malignant result in $69 \%$ of 29 lesions suspect on palpation, but in only $22 \%$ of non-suspect palpable lesions.

The clinical symptoms pointing to malignancy included a bloody nipple discharge in $40 \%$ and skin retraction in $100 \%$. However, $36 \%$ of the benign papillomas also had a bloody discharge. When there was no bloody discharge, the percentage malignancy was much lower at 15.4\%. Among the B3 lesions, 203 had no clinical symptoms. Nevertheless, $25 \%$ of the lesions were malignant, so an unclear imaging or biopsy result cannot be revised based on an absence of symptoms.

All patients had follow-up for 1 to 7 years (mean 3 years). It should be noted that surgery was not performed in 48 cases. In this subgroup, no malignancies occurred after 14 core biopsies and 34 vacuum biopsies. In the 254 patients who had primary surgery, 5 malignancies (3\%) occurred in the previous operation field during follow-up of 163 lesions previously confirmed by core biopsy, three of them after a papilloma and two after ADH. One malignancy (3.3\%) after $\mathrm{ADH}$ in the previous biopsy region
- Table 1 Frequencies of B3 lesions in all needle biopsies.

\begin{tabular}{|l|c|c|}
\hline $\begin{array}{l}\text { B3 lesions in all } \\
\text { needle biopsies }\end{array}$ & $\begin{array}{l}\text { absolute } \\
\text { frequency }\end{array}$ & $\begin{array}{l}\text { relative } \\
\text { frequency } \\
\text { (in percent) }\end{array}$ \\
\hline Papilloma & 135 & $44.0 \%$ \\
\hline radial scar & 18 & $5.9 \%$ \\
\hline Phyllodes tumour & 20 & $6.5 \%$ \\
\hline ADH & 70 & $22.8 \%$ \\
\hline FEA & 29 & $9.4 \%$ \\
\hline atypical apocrine metaplasia & 2 & $0.7 \%$ \\
\hline fibroadenoma with atypia & 1 & $0.3 \%$ \\
\hline complex fibroadenoma & 10 & $3.3 \%$ \\
\hline adenomyoepithelioma & 2 & $0.7 \%$ \\
\hline LIN 1 & 15 & $4.9 \%$ \\
\hline LIN 2 & 5 & $1.6 \%$ \\
\hline total & 307 & $100.0 \%$ \\
\hline
\end{tabular}

- Table 2 Frequencies of B3 lesions in core biopsies.

\begin{tabular}{|l|c|c|}
\hline B3 lesions in core biopsies & $\begin{array}{c}\text { absolute } \\
\text { frequency }\end{array}$ & $\begin{array}{c}\text { relative } \\
\text { frequency } \\
\text { (in percent) }\end{array}$ \\
\hline Papilloma & 105 & $54.5 \%$ \\
\hline radial scar & 9 & $4.7 \%$ \\
\hline Phyllodes tumour & 20 & $10.5 \%$ \\
\hline ADH & 31 & $15.7 \%$ \\
\hline FEA & 8 & $4.2 \%$ \\
\hline atypical apocrine metaplasia & 2 & $1.0 \%$ \\
\hline fibroadenoma with atypia & 1 & $0.5 \%$ \\
\hline complex fibroadenoma & 9 & $4.7 \%$ \\
\hline adenomyoepithelioma & 2 & $1.0 \%$ \\
\hline LIN 1 & 4 & $2.1 \%$ \\
\hline LIN 2 & 2 & $1.0 \%$ \\
\hline total & $\mathbf{1 9 3}$ & \\
\hline
\end{tabular}

occurred during follow-up of the 77 patients who had primary surgery of a lesion confirmed by vacuum-assisted biopsy.

\section{Relevance of imaging}

The frequencies of the BI-RADS categories of B3 lesions differ in ultrasound and mammography ( $\triangleright$ Fig. 1, 2). Both imaging methods were used in all patients. The pretreatment mammogram result was not available in 13 cases, however, and the indication for surgery was based on the ultrasound. Most malignancies were classified as BI-RADS 4 - 5 with both imaging methods. However, 23 of 114 cases (20\%) were incorrectly assessed on 
- Table 3 Frequencies of B3 lesions in vacuum-assisted biopsies.

\begin{tabular}{|l|r|r|}
\hline $\begin{array}{l}\text { B3 lesions in } \\
\text { vacuum-assisted biopsies }\end{array}$ & $\begin{array}{l}\text { absolute } \\
\text { frequency }\end{array}$ & $\begin{array}{l}\text { relative frequency } \\
\text { (in percent) }\end{array}$ \\
\hline Papilloma & 30 & $26.3 \%$ \\
\hline radial scar & 9 & $7.9 \%$ \\
\hline ADH & 39 & $34.2 \%$ \\
\hline FEA & 21 & $18.4 \%$ \\
\hline Complex fibroadenoma & 1 & $0.9 \%$ \\
\hline LIN 1 & 11 & $9.6 \%$ \\
\hline LIN 2 & 3 & $2.6 \%$ \\
\hline total & $\mathbf{1 1 4}$ & $\mathbf{1 0 0 . 0} \%$ \\
\hline
\end{tabular}

- Table 4 Frequencies of benign and malignant operation results.

\begin{tabular}{|l|l|l|r|}
\hline $\begin{array}{l}\text { B3 lesions in core } \\
\text { biopsies }\end{array}$ & $\begin{array}{l}\text { operation result } \\
\text { absolute und relative } \\
\text { frequency (in percent) }\end{array}$ & \\
\hline & benign & malignant & \\
\hline Papilloma & $86(75.4 \%)$ & $28(24.6 \%)$ & 114 \\
\hline radial scar & $14(77.8 \%)$ & $4(22.2 \%)$ & 18 \\
\hline $\begin{array}{l}\text { Phyllodes } \\
\text { tumour }\end{array}$ & $19(95 \%)$ & $1(5 \%)$ & 20 \\
\hline ADH & $32(51.6 \%)$ & $30(48.4 \%)$ & 62 \\
\hline FEA & $17(100 \%)$ & $0(0 \%)$ & 17 \\
\hline $\begin{array}{l}\text { atypical apocrine } \\
\text { metaplasia }\end{array}$ & $1(50 \%)$ & $1(50 \%)$ & 2 \\
\hline $\begin{array}{l}\text { complex } \\
\text { fibroadenoma }\end{array}$ & $4(100 \%)$ & $0(0 \%)$ & 4 \\
\hline $\begin{array}{l}\text { Adenomyo- } \\
\text { epithelioma }\end{array}$ & $1(50 \%)$ & $1(50 \%)$ & 2 \\
\hline LIN 1 & $9(81.8 \%)$ & $2(18.2 \%)$ & 11 \\
\hline LIN 2 & $2(50 \%)$ & $2(50 \%)$ & 4 \\
\hline total & $\mathbf{1 8 5}(\mathbf{7 2 . 8} \%)$ & $\mathbf{6 9}(\mathbf{2 7 . 2} \%)$ & 254 \\
\hline
\end{tabular}

ultrasound as BI-RADS categories 1 - 3, and this occurred in 19 of 85 cases ( $22 \%$ ) on mammography. The false-negative ultrasound results were lesions apparent on mammography without a corresponding sonographic finding. The converse applied in the case of false-negative mammograms.

The B3 lesions that were assessed on imaging as suspicious for malignancy were actually malignant in $32.9 \%$ of ultrasound scans and in $29.5 \%$ of the mammograms ( $\triangleright$ Table 7,8 ). Suspicious microcalcification was apparent in 138 of the 291 mammograms. Comparison of mammogram reports with and without microcalcification did not find any differences with regard to specificity. The results show that the two imaging methods are complementary. This also influences the interventional investigation method.
- Table 5 Frequencies of benign and malignant operation results in core biopsies.

\begin{tabular}{|l|c|c|c|}
\hline $\begin{array}{l}\text { B3 lesions in } \\
\text { core biopsies }\end{array}$ & $\begin{array}{l}|l| \\
\text { operation result } \\
\text { absolute und relative } \\
\text { frequency (in percent) }\end{array}$ & total \\
\hline & benign & malignant & \\
\hline Papilloma & $70(73.7 \%)$ & $25(26.3 \%)$ & 95 \\
\hline radial scar & $6(66.7 \%)$ & $3(33.3 \%)$ & 9 \\
\hline Phyllodes tumour & $19(95 \%)$ & $1(5 \%)$ & 20 \\
\hline ADH & $10(33.3 \%)$ & $20(66.7 \%)$ & 30 \\
\hline FEA & $7(100 \%)$ & $0(0 \%)$ & 7 \\
\hline atypical apocrine & $1(50 \%)$ & $1(50 \%)$ & 2 \\
\hline metaplasia & $3(100 \%)$ & $0(0 \%)$ & 3 \\
\hline complex fibroadenoma & $1(50 \%)$ & $1(50 \%)$ & 2 \\
\hline Adenomyoepithelioma & $3(100 \%)$ & $0(0 \%)$ & 3 \\
\hline LIN 1 & $1(50 \%)$ & $1(50 \%)$ & 2 \\
\hline LIN 2 & $121(69.9 \%)$ & $\mathbf{5 2}(\mathbf{3 0 . 1} \%)$ & 173 \\
\hline total & & & \\
\hline
\end{tabular}

- Table 6 Frequencies of benign and malignant operation results in vacuum-assisted biopsies.

\begin{tabular}{|l|l|l|l|}
\hline $\begin{array}{l}\text { B3 lesions in } \\
\text { vacuum-assisted } \\
\text { biopsies }\end{array}$ & \multicolumn{2}{|l|}{$\begin{array}{l}\text { operation result } \\
\text { absolute und relative } \\
\text { frequency (in percent) }\end{array}$} & \\
\hline benign & malignant & \\
\hline Papilloma & $15(83.3 \%)$ & $3(16.7 \%)$ & 18 \\
\hline radial scar & $8(88.9 \%)$ & $1(11.1 \%)$ & 9 \\
\hline ADH & $21(67.7 \%)$ & $10(32.3 \%)$ & 31 \\
\hline FEA & $10(100.0 \%)$ & $0(0 \%)$ & 10 \\
\hline complex & $1(100 \%)$ & $0(0 \%)$ & 1 \\
\hline fibroadenoma & $6(75.0 \%)$ & $2(25.0 \%)$ & 8 \\
\hline LIN 1 & $1(50 \%)$ & $1(50 \%)$ & 2 \\
\hline total & $\mathbf{6 2 ( 7 8 . 5 \% )}$ & $\mathbf{1 7}(\mathbf{2 1 . 5} \%)$ & $\mathbf{7 9}$ \\
\hline
\end{tabular}

Mammographically suspicious microcalcification was confirmed by stereotactic vacuum-assisted biopsy, whereas suspicious ultrasound findings were confirmed by core needle biopsy. This preselection explains the differences in frequency of the various B3 lesions and the different frequencies of malignancy in subsequent surgery. This must be taken into account when interpreting the results and determining further action. 


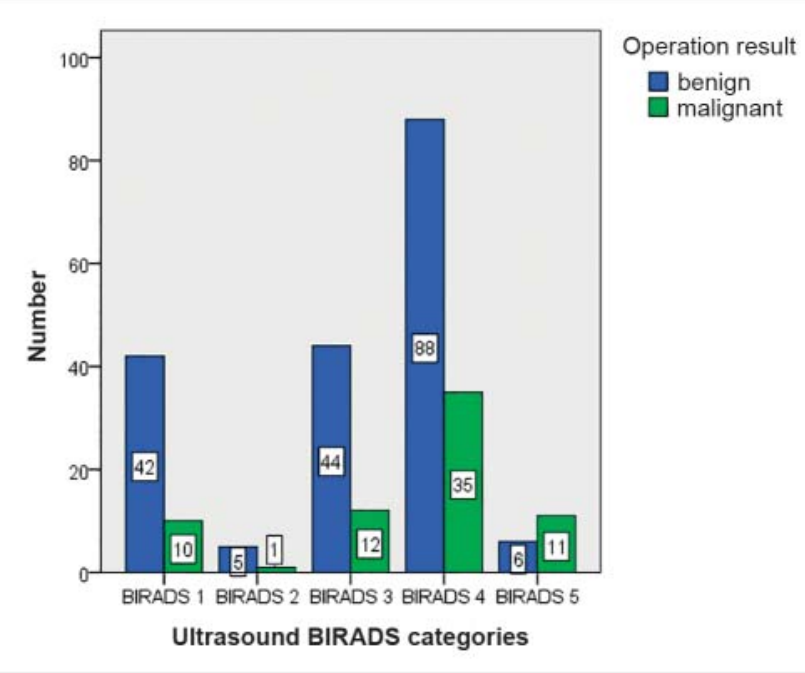

- Fig. 1 Absolute frequencies of ultrasound BI-RADS categories depending on operation result.

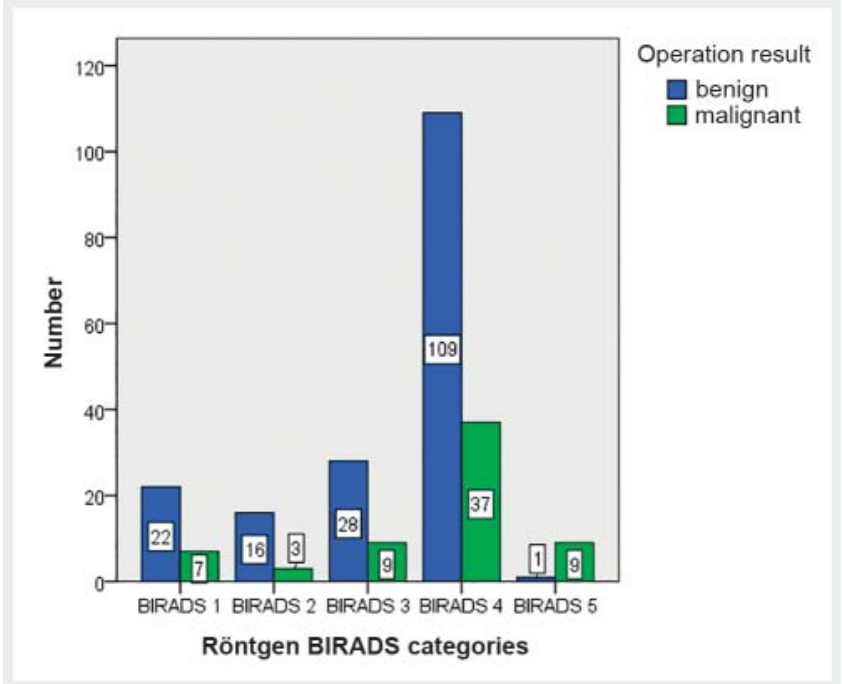

- Fig. 2 Absolute frequencies of X-ray BI-RADS categories depending on operation result.

\section{Comparison between screening and non-screening patients:}

Our study includes 86 patients from the mammography screening programme. More core needle biopsies (191) than vacuum-assisted biopsies (114) were performed overall. By contrast, the rate of investigation of screened patients by vacuum biopsy is markedly higher at $67 \%$ than the rate of core needle biopsies (33\%). This is explained by the more frequent investigation of microcalcification found on primary mammography compared with sonography. As expected, the distribution pattern of the different B3 lesions in the screened patients corresponds to the mammographic lesions diagnosed by vacuum biopsy in the patients overall ( $\triangleright$ Table 3,6 ) and differs substantially from the results obtained from ultrasound-guided core needle biopsies ( $>$ Table 2,5 ). A surgical diag-
- Table 7 Frequencies of ultrasound assessment depending on operation result.

\begin{tabular}{|l|l|l|l|}
\hline US assessment & \multicolumn{2}{|l|}{$\begin{array}{l}\text { operation result } \\
\text { absolute und relative } \\
\text { frequency (in percent) }\end{array}$} & total \\
& benign & malignant & \\
\hline benign & $91(79.8 \%)$ & $23(20.2 \%)$ & 114 \\
\hline malignant & $94(67.1 \%)$ & $46(32.9 \%)$ & 140 \\
\hline total & $\mathbf{1 8 5}(\mathbf{7 2 . 8} \%)$ & $\mathbf{6 9}(\mathbf{2 7 . 2} \%)$ & $\mathbf{2 5 4 ( 1 0 0 . 0 \% )}$ \\
\hline
\end{tabular}

Sensitivity 0.67 ; Specificity 0.49 ; ppv 0.33 ; npv 0.8 .

- Table 8 Absolute and relative frequencies of X-ray assessment depending on operation result.

\begin{tabular}{|l|l|l|l|}
\hline $\begin{array}{l}\text { X-ray } \\
\text { assessment }\end{array}$ & $\begin{array}{l}\text { operation result } \\
\text { absolute und relative } \\
\text { frequency (in percent) }\end{array}$ & total \\
& benign & malignant & \\
\hline benign & $66(77.6 \%)$ & $19(22.4 \%)$ & 85 \\
\hline malignant & $110(70.5 \%)$ & $46(29.5 \%)$ & 156 \\
\hline total & $\mathbf{1 7 6}(\mathbf{7 3 . 0} \%)$ & $\mathbf{6 5}(\mathbf{2 7 . 0} \%)$ & $\mathbf{2 4 1}(\mathbf{1 0 0 . 0} \%)$ \\
\hline Sensitivity 0.71; Specificity 0.38; ppv 0.29; npv 0.78. & \\
\hline
\end{tabular}

nosis was made in $76 \%$ of screened patients and in $86 \%$ of nonscreened patients.

\section{Discussion}

Our retrospective analysis of lesions that were unclear on ultrasound and/or mammography considered only lesions classified pathologically as B3 lesions, as it is particularly important to interpret these and determine further action [1, 2]. This is also made more difficult by the fact that the results of various studies sometimes show marked differences in the frequencies of the various B3 lesions and also in the rate of malignancy. We had a mixed patient population in which there was a similar selection of lesions that were confirmed by stereotactic vacuum-assisted biopsy or diagnosed by ultrasound-guided core needle biopsy. This is due to the fact that ADH often appears through clusters of microcalcification, which is identified much better on mammography than on ultrasound. By contrast, papillomas are usually soft tissue tumours without microcalcification. These are readily identified on ultrasound as they are in intraductal or intracystic location and offer very good imaging contrast due to the surrounding fluid. Conversely, they are difficult to detect mammographically 
because of radiation absorption by the surrounding fluid or dense parenchyma.

This also explains the high false-negative rates of the two diagnostic methods ( $\triangleright$ Fig. 1,2 ), as the other method was superior in each case depending on the imaging characteristics. Consequently, further investigation is required in every case when a lesion is detected by mammography and/or ultrasound that cannot be otherwise refuted beyond doubt.

Interestingly, this also affects the proportion of malignant surgical results after previous core needle or vacuum-assisted biopsy $(\triangleright$ Table 5, 6). When ultrasound-guided core biopsy showed a papilloma, cancer was present in $26.3 \%$ of open biopsies, and in $66.7 \%$ of cases of ADH confirmed by core biopsy. On the other hand, the malignancy rate after vacuum biopsy was only $16.7 \%$ in the case of papilloma and $32.3 \%$ with $\mathrm{ADH}$. This is explained by the much larger tissue sample resected by vacuum biopsy so that a cancer present beside the B3 lesion is found directly in the vacuum biopsy specimen. Because of the smaller tissue sample, core biopsy often cannot distinguish with certainty between $\mathrm{ADH}$ and DCIS, or concomitant DCIS may not be detected with a papilloma. In each case, the results show that a high percentage of malignant tumours are concealed behind B3 lesions or accompany these.

According to Aulmann, papillomas account for $28 \%$ of all B3 lesions, FEA for $26 \%$, ADH for $20 \%$, radial scars for $14 \%$, LIN for $13 \%$, atypical fibroadenomas for $4 \%$ and phyllodes tumours for $3 \%$ [3]. In a large multicentre study over an 11-year period, Bianchi et al. compared the histopathological results of 1644 B3 lesions confirmed by vacuum biopsy [5]. ADH was most frequent at $43.9 \%$, followed by LIN at $22.9 \%$, FEA at $14.9 \%$, papillomas at $8.2 \%$ and radial scars at $8 \%$. In our patients, by contrast, the following was the distribution of the B3 lesions: papillomas $44 \%$, ADH $22.8 \%$, FEA 9.4\%, phyllodes tumours $6.5 \%$, radial scars $5.9 \%$, LIN $14.9 \%$, complex fibroadenomas $3.3 \%$ and LIN $21.6 \%$ ( $\downarrow$ Table 1 ). When we consider our results separately according to biopsy method, $A D H$ is the most frequent lesion confirmed by vacuum biopsy, whereas papilloma is much more frequent among lesions diagnosed by ultrasound-guided core needle biopsy ( $\vee$ Table 2, 3). This is confirmed by other researchers [6, 7]. These large differences can be easily explained if it is recalled that the study by Bianchi et al. investigated only mammographic lesions by stereotactic vacuum-assisted biopsy [5]. This means that lesions with clustered microcalcification are highly selected.

This does not mean that core needle biopsy is unreliable for histological diagnosis. It is regarded internationally as gold standard and achieves a sensitivity and specificity of well over $90 \%$ [812]. However, careful correlation between imaging and histology at the clinical pathology conference is important, especially because of the smaller tissue sample. More patients therefore had surgery after a core needle biopsy, while more non-operated patients had previously had vacuum-assisted biopsy. Rajan et al. showed in their study that the number of surgical excisions can be reduced by vacuum-assisted biopsy and the number of preoperative breast cancer diagnoses can be increased [13]. The meta-analysis by Fahrbach et al. confirms that the rate of underestimation is lower with vacuum-assisted biopsy than with core needle biopsy [14]. It should be noted, however, that only vacuum-assisted biopsy under stereotactic control is reimbursable in Germany. By contrast, it is also performed under ultrasound control in many countries.

The fact that both stereotactic and MRI- and ultrasound-guided vacuum biopsies are reimbursable in Switzerland led to a completely different process of minimally invasive diagnosis and treatment of B3 lesions [15]. From 2009 to 2015, 22072 vacuumassisted biopsies were performed, $69 \%$ stereotactic, $23 \%$ ultrasound-guided and $8 \%$ MRI-guided. 3344 B3 lesions were diagnosed. Subsequent open excision was performed in only $33 \%$ of cases and malignancy was found in $22 \%$ (15\% DCIS, 7 \% invasive cancer). Based on these results and on a review of extensive data in the literature, the following recommendations were issued in an international consensus conference:

When $\mathrm{ADH}$ is confirmed after core needle or vacuum-assisted biopsy, it should usually be excised by open biopsy. If FEA is diagnosed by core needle biopsy, excision by open biopsy or vacuumassisted biopsy is recommended. If the diagnosis is confirmed by the vacuum biopsy, further open excision is not necessary if the lesion was circumscribed on imaging and was removed completely by the procedure. The same applies for lobular neoplasia and radial scars. Papillomas should be confirmed and removed by vacuum-assisted biopsy. Phyllodes tumours should generally undergo primary excision. If a benign phyllodes tumour is confirmed by vacuum biopsy, open excision biopsy can be omitted if it has been fully removed. This corresponds fundamentally to the current recommendations of the latest 2017 version of the S3 guidelines [16]. However, there is some discrepancy with the current AGO Mamma recommendations [17]. The malignancy rates reported there are much lower than in our patients and in all literature references we are aware of. In the recommendations for surgery, a distinction is not made between diagnosis by core needle or vacuum-assisted biopsy, which we regard as extremely problematic. An inexperienced researcher could easily draw incorrect conclusions as the histological sample obtained from core needle biopsies is not sufficiently representative compared with the larger-volume vacuum-assisted biopsy. In view of the relatively high rate of cancer, the recommendations on overall follow-up are too liberal, especially if open excision biopsy has not been performed. The only recommendation is a follow-up screening mammogram every 2 years or every 12 months after ADH or LIN. However, this does not take into account the fact that many of these lesions are not detected mammographically at all, according to our comparison of mammography and ultrasound.

Our final recommendations on how to proceed with B3 lesions diagnosed by interventional biopsy coincide very well with the current S3 guidelines on the diagnosis and treatment of breast cancer [16] and the recommendations of the international consensus conference in Zürich [15]. It should be pointed out that there are no randomised or prospective study data; however, all recent retrospective studies suggest that careful individual assessment in interdisciplinary conferences can reduce the rate of open biopsies of B3 lesions in suitable cases.

In this regard, reimbursement of the cost of the two interventional investigation methods in Germany should be examined critically, especially as ultrasound-guided vacuum biopsy was used very often before the introduction of an EBM number for ste- 
reotactic vacuum-assisted biopsy. In these cases, the cost was reimbursed on individual application to the health insurance companies. When correctly indicated, this was regularly approved. As can be seen from the Swiss data [15] and the current guideline recommendations [16], open biopsies can be avoided in many cases, especially by vacuum-assisted biopsy under ultrasound control. This demand is expressly emphasised by the consensus statement on the importance of vacuum-assisted biopsy under ultrasound control produced by Hahn et al. [18].

In this connection, the reimbursement in the German health system must be criticised as it does not cover the cost of performing vacuum biopsy (stereotactic and MRI-guided), including when compared with other countries [19]. This merits detailed consideration by those responsible as the scientific data show clearly that open surgical biopsies can be substantially reduced by vacuum-assisted biopsy. Apart from the considerably lower burden for affected patients, costs could also be greatly reduced.

\section{Conflict of Interest}

The authors declare that they have no conflict of interest.

\section{References}

[1] Bettendorf U, Fisseler-Eckhoff A. Die Rolle des Pathologen im Mammografiescreening. Der Pathologe 2009; 30 (1): $20-30$

[2] Amendoeira I. Quality assurance guidelines for pathology: Cytological and histological non-operative procedures. In: Perry N, Broeders M, de Wolf $\mathrm{C}$, et al., Eds.; European guidelines for quality assurance in breast cancer screening and diagnosis. 4th Luxembourg: Office for Official Publications of the European Communities; 2006: 221 - 256

[3] Aulmann S. B3-Läsionen - was ist das? Med Review 2011; 12: 17

[4] Böcker W, Kreipe H. Kapitel 42: Mamma. In: Böcker W, Denk H, Heitz PU, et al., Hrsg Pathologie. 5. Aufl. München: Urban und Fischer; 2012: 811-826

[5] Bianchi S, Caini S, Renne G et al. Positive predictive value for malignancy on surgical excision of breast lesions of uncertain malignant potential (B3) diagnosed by stereotactic vacuum-assisted needle core biopsy (VANCB): a large multi-institutional study in Italy. Breast (Edinburgh, Scotland) 2011; 20 (3): 264-270

[6] Houssami N, Ciatto S, Bilous M et al. Borderline breast core needle histology: predictive values for malignancy in lesions of uncertain malignant potential (B3). Br J Cancer 2007; 96 (8): 1253-1257
[7] Ciatto S, Houssami N, Ambrogetti D et al. Accuracy and underestimation of malignancy of breast core needle biopsy: the florence experience of over 4000 consecutive biopsies. Breast cancer research and treatment 2007; 101: 291-307

[8] Pagni F, Bosisio FM, Salvioni D et al. Application of the British National Health Service Breast Cancer Screening Programme classification in 226 breast core needle biopsies: correlation with resected specimens. Annals of diagnostic pathology 2012; 16 (2): 112-118

[9] Schulz-Wendtland R, Aichinger U, Kramer S et al. Sonographical breast biopsy: how many core biopsy specimens are needed? Fortschr Röntgenstr 2003; 175 (1): $94-98$

[10] El-Sayed ME, Rakha EA, Reed J et al. Audit of performance of needle core biopsy diagnoses of screen detected breast lesions. European journal of cancer 2008; 44 (17): 2580-2586

[11] Willems SM, van Deurzen CH, van Diest PJ. Diagnosis of breast lesions: fine-needle aspiration cytology or core needle biopsy? A review. Journal of clinical pathology 2012; 65 (4): 287-292

[12] Buchberger W, Niehoff A, Obrist P et al. Sonographically guided core needle biopsy of the breast: technique, accuracy and indications. Der Radiologe 2002; 42 (1): 25-32

[13] Rajan S, Shaaban AM, Dall BJG et al. New patient pathway using vacuumassisted biopsy reduces diagnostic surgery for B3 lesions. Clinical radiology 2012; 67 (3): 2449

[14] Fahrbach K, Sledge I, Cella C et al. A comparison of the accuracy of two minimally invasive breast biopsy methods: a systematic literature review and meta-analysis. Archives of gynecology and obstetrics 2006; 274 (2): $63-73$

[15] Rageth C], O'Flynn EAM, Comstock C et al. First International Consensus Conference on lesions of uncertain malignant potential in the breast (B3 lesions). Breast Cancer Res Treat 2016; 159 (2): 203-213

[16] Leitlinienprogramm Onkologie: S3-Leitlinie Früherkennung, Diagnose, Therapie und Nachsorge des Mammakarzinoms, Version 4.0, 2017 AWMF Reg. Nr. 032-0450L.

[17] Empfehlungen der AGO zur Diagnostik und Therapie von Patientinnen mit primärem und metastasiertem Brustkrebs. AGO Kommission Mamma der DGGG und DKG. 2018

[18] Hahn M, Krainick-Strobel U, Toellner T et al. Interdisciplinary consensus recommendations for the use of vacuum-assisted breast biopsy under sonographic guidance: first update 2012. Ultraschall in der Medizin 2012; 33 (4): 366-371

[19] Hahn M, Fischbach E, Fehm T et al. Ist die Mammabiopsie ausreichend finanziert? Eine Prozesskosten \& Erlösbetrachtung. Fortschr Röntgenstr 2011; 183: 347-357 